\title{
L2 Teachers' Knowledge of L2 Learners' Listening and Oral Interpretation Problems: Any Correspondence?
}

\author{
Karim Sadeghi \\ Urmia University, Iran \\ kerimsadeghi@gmail.com
}

\author{
Mohammad Ali Rahimi \\ Urmia University, Iran
}

\begin{abstract}
The study was aimed at comparing learners' knowledge of their listening and oral interpretation problems with their teachers' perception and knowledge of the same problems. Fifty two learners in company with their three instructors participated in the study. The study tapped the students' reflections on cognitive, affective and linguistic factors impinging on listening and oral interpretation processes and teachers' perception and knowledge of the same real time listening and interpretation tasks. Introspection techniques, observation and interviews were the main techniques of data collection. Data analysis revealed many congruencies between the learners and their instructors in terms of the listening experiences and perceptions. They included such themes as 'ineffective strategy of focusing on words', 'speedy delivery', 'difficulty level of the material', 'accent effect' and 'parsing problem'. However, some discrepancies were also identified with regard to such core themes as 'modality' and affective issues such as 'stress', 'sense of fatigue' and 'concentration loss'. The results suggest that instructors' perception and awareness of their learners' listening processing and oral translation skills coupled with those of learners can provide rich information in developing listening and oral interpretation programs for translation students and trainers.
\end{abstract}

Keywords: oral interpretation, listening processing, knowledge, perception

\section{Introduction}

Prior to 1970s, listening was considered as a receptive and passive skill Johnson, 2008; Vandergrift, 2011), but with the appearance of communicative approaches to language teaching, listening came to be assumed as an active and very complex process where the listener uses various linguistic and non-linguistic resources to rapidly interpret incoming data (Jinhong, 2011). To interpret oral input, listeners are to elicit their background knowledge (top-down processing) to perceive, interpret, and respond to the information coming from a text (bottom-up processing) (Lynch \& Mendelsohn, 2009; O’Malley, Chamot \& Küpper, 1989). However, what compounds the listening task for the oral English interpreters is the subsequent, or at many contexts, the concurrent complicated process of interpretation. Oral interpretation apprentices undergo undue difficulties listening and at the same time interpreting oral input. To identify and

ISSN |2355-3669| E-ISSN | 2503-2518| Volume 6| Number 2|December 2019|

Available online at http://jurnal.radenfatah.ac.id/index.php/edukasi 
then to lessen the listening processing and oral interpretation problems studies with varied focuses are to be conducted in situ involving both the learners and instructors. Views from both groups can provide insightful information in preparing training programs for the learners.

To get a realistic picture of and to overcome the obstacles experienced by L2 learners during the listening process, the participants' real 'knowledge' of their own listening problems is of optimum significance. 'Knowledge' implies an objective understanding, what one knows to be true instead of what one holds to be true which is termed as 'belief' (Wenden, 1999). L2 learners' 'knowledge' of their listening relevant processes/problems emanating directly from their experiences with L2 listening is really promising in helping them alleviate those problems on the spot. To approach this objective, qualitative studies are to be conducted in the context in which listening activities are carried out.

Many studies have been conducted to investigate the complex process of listening in L2, in general (Field, 2004; Goh, 2000; Vandergrift \& Tafaghodtari, 2010). L2 listening particularly in contexts requiring its company with interpretation makes it more complex and demanding. Interpretation, according to Mahmoodzadeh (1992) is to reflect simultaneously or consecutively in the target language the precise meaning of source language utterance while preserving "the tone of the speaker" (p.231). Consecutive interpretation comes after the speaker stops articulating the source utterance, whereas in simultaneous mode, interpretation occurs when the interpreter is still receiving utterance. Phelan (2001) asserts that "The interpreter needs a good short-term memory to retain what he or she has just heard and a good long-term memory to put the information into context" (p.4-5). Ability to concentrate is a factor as is the ability to analyze and process what is heard.' He emphasizes the difficulties and efforts involved in interpreting tasks. Interpretation, according to Gile, needs much memory effort which stems from the need to store the words of a proposition until the hearer receives the end of that proposition.

Since L2 learners training to be interpreters encounter many communication problems not only during the training sessions but also in the actual interpretation task, the training programs, therefore, should provide them with an ability to successfully manage the ongoing interpretation process in such situations. To have an informed knowledge of how to deal with more demanding listening processes transpiring in 'interpretation activity' we should try to discover and analyze the listening relevant problems naturally relevant to this context. The current study investigates the problems from the viewpoints of instructors and learners and the following question was posited for further scrutiny: Does L2 learners' knowledge of their listening and interpretation problems correspond with their teachers' knowledge and perception of the same problems?

\section{Literature Review}

\section{Listening processing and sources of problems}

Listening process in L1 is carried out automatically without paying much conscious and focal attention to the incoming data. EFL listeners, however, need to pay conscious attention to the details to construct a meaning out of a text heard and their limited working memory and linguistic knowledge may impede this process (Vandergrift, 2004).

The main purpose of second language listening programs is to develop active listeners (Goh, 2013). Active listening is to build reasonable interpretations with underspecified input (Goh, 2013). It requires a command of linguistic and cognitive ability coupled with affective control (Elkhafaifi, 2005). Linguistic factors include (a) familiarity with and ability to understand the phonology of the language, (b) vocabulary size, and (c) background knowledge about the 
topic, text, structure, schema, etc. and cognitive factors encompass working memory and metacognitive strategies such as planning, prediction, monitoring, evaluation, mental translation, personal knowledge, and directed attention. Affective factors include such important aspects as anxiety and motivation which often play determining roles in L2 listening process.

Due to the complexity of L2 listening development, attempts have been made to identify main factors instigating comprehension problems during L2 listening and various studies have tried to probe their differential effects. Five factors were reported by Goh (1999) to be influencing listening: vocabulary used in the text, prior knowledge of the passage's theme, speech rate, type of input and speaker's accent. Goh (2000) working within Anderson's (1985) threephase model of language comprehension perception, parsing and utilization - found that most of the listeners suffered perceptual processing, indicative of low level processes, and only a few problems such as parsing and utilization were relevant to the high level processes. Similarly, Hasan (2000) investigating Arabic EFL learners maintained that most frequently reported problems by EFL listeners were of bottom-up nature such as fast speech rate and new vocabulary although factors such as task, text, speaker and listener were also identified. Graham's (2006) study also found listening problem of perceptual nature. His investigation revealed that speedy delivery of speech culminates in failure in identifying and recognizing words in a stream of input. In like fashion, Vogely's (1995) English students of Spanish encountered such perceptual processing problems as combining words into phrases, recognizing words and recognizing grammatical structures.

Other sources of listening difficulties have been reported. Brown (1995), not denying the existence of problems just mentioned argued that content of the texts is often an impediment in the processing of oral input. Listeners in ESP context found some idiomatic and fixed expressions especially those with sociocultural connotations problematic (Goh, 2013). Noro (2006) "brought into light the listening stress in EFL contexts stating that L2 Listening contexts are often "some sort of stressor(s)" which cause anxiety called "listening stress"'(p.64). Along the same line, Chang (2008) found a relationship between listening tasks and listening anxiety and further suggested that some 'listening supports' can help reduce such anxieties. Other affective reactions germane to L2 listening activities are irritation, lack of concentration, aversion, sense of resignation and loss of self-confidence (Noro, 2006).

Findings on cognitive, linguistic and affective factors influencing listening process in L2 can be displayed as follows:

Table 1. Cognitive, linguistic and affective factors affecting L2 listening processing

\begin{tabular}{lll} 
Problem type & Findings & Researchers \\
\hline
\end{tabular}

Linguistic Studies show that the listening problems encountered by

Goh (2013)

L2 learners are related mainly to fundamental cognitive

processes for example, accent and vocabulary.

Linguistic knowledge, which can be implicit or explicit, is

(Anderson, used for linguistic cues.

2009)

ISSN |2355-3669| E-ISSN | 2503-2518| Volume 6| Number 2|December 2019|

Available online at http://jurnal.radenfatah.ac.id/index.php/edukasi 
L2 learners face an important obstacle in distinguishing content words and function words when their L1 does not resemble English rhythmically.

lack of clarity of spoken language caused by assimilation or unclear articulation makes word segmentation an extremely difficult task for L2 listeners

to many L2 listeners, the spoken language is like "a wave of sounds without borderlines".

Linguistic knowledge contributes to listening comprehension: they include phonology, lexis, syntax, semantics and discourse structure.

\section{Cognitive} Metacognitive strategies instruction are effective for advanced-level learners.

Such metacognitive strategies as predicting, monitoring, responding, clarifying, inferencing, and evaluating are useful for fostering strategy awareness and supporting learner autonomy.

Making sense of spoken text is the result of continuous and interactive top-down and bottom-up processing.

Greater performance was found to be related to greater working memory

L2 proficiency and L1 listening ability together play a role in successful L2 listening.

Affective
Listening to what students want to listen to is really motivating for them and keeps them engaged.

Listening supports such as topic preparation and repeated input reduces learners' anxiety on listening tests.

There exists a psychological reality of the construct like listening stress as identified by studying Japanese college students.

Listening can induce anxiety in L2 learners.

Positive relationship has been found between motivation and listening success.
(Field, 2009;

Eastman, 1993)

(Stahr, 2009)

(Buck, 2001)

Cross (2009)

(Lynch, 2009)

(Goh, 2008;

Vandergrift, 2007).

(Leeser, 2007)

(Vandergrift, 2006)

(Kemp, 2010)

Chang (2008)

(Noro, 2006)

(Elkhafaifi, 2005)

(Vandergrift, 2005) 
Motivation in L2 listening is really important since

listening needs a conscious attention and involvement.

(Rost, 2001)

Note: cognitive, linguistic and affective factors affecting L2 listening processing

\section{Methods \\ Research design}

Both qualitative and quantitative analyses were conducted. Qualitative analysis was aimed at providing a categorization scheme and the categories were to be derived directly from the data without employing any predetermined coding scheme (Friedman, 2012). The researchers extracted some recurrent patterns and core themes from the initial qualitative data from students' reflection

\section{Research site and participants}

Both students and the instructors studying and teaching Translation at Payam Noor University in Zanjan, Iran, were investigated. They attended "oral interpretation" classes after passing courses in 'Speaking and Listening 1' and 'Speaking and Listening 2'. Besides, a paperbased TOEFL test was administered prior to the outset of the program and it was found that students were at lower level of English language proficiency. The composition of the groups taking part in the study was 22, 16 and 14 for each class ( $\mathrm{n}=52,34$ females and 18 males). Three voluntary instructors participated in this study. They had taught oral translation at least for 8 years at different universities of Iran. One of the researchers of this project was among the instructors who had 12 years of experience in teaching oral translation.

\section{Data collection and data analyses}

Different instruments were utilized at various stages: A TOEFL test was conducted to ensure the participants' homogeneity; and to gather data about learners' listening and interpretation problems, introspection techniques were employed. Teachers' 'observation' of their students' listening and interpretation activities was included to report on students' listening and interpretation processes.

Verbalization techniques (introspective and retrospective) were used to tap learners' reflections on mental processing, affective factors and linguistic controls both during (selfrevelation) and immediately following (self-observation) the listening processing and interpretation activities (Mackey \& Gass, 2016). Learners' knowledge of listening experiences mainly included "insights into real-time problems that they faced during listening and interpretation" (Goh, 1999, p. 57). Instructors' perception relating to the learners' listening and interpretation problems came from their observation of the listeners' actions and reactions during real-time processing and from their general views about the same activities. Instructors were also interviewed at the end of every session and were recorded for subsequent analysis.

Oral translation classes were held for eight sessions but data were gathered from the respondents every other session (4 sessions). To help the researchers with the quantification and interpretation of the findings, the themes explored from the learners' data were also used as a basis for the analysis of the instructors' data in terms of listening comprehension and oral interpretation problems. 
Both qualitative and quantitative analyses were conducted. Qualitative analysis was aimed at providing a categorization scheme and the categories were to be derived directly from the data without employing any predetermined coding scheme (Friedman, 2012). The researchers extracted some recurrent patterns and core themes from the initial qualitative data from students' reflection. The on-going analyses for each class were reviewed for recurrent patterns and a list of themes for each class was drawn up. The listed themes were cross-referenced to each class to see whether a theme was present or absent. Following the exploration of core issues in terms of listening and interpretation problems, subsequent data from both students and teachers were analyzed quantitatively in terms of those pivotal categories.

Table 2 (in Results' Section) provides the percentage rate of the students who reported a certain problematic issue. During and immediately after the listening and interpretation activities, we asked students to mark what listed problems (written categorized problems) as well as to write what unlisted new difficulties they experienced, thereby identifying the number of the students with particular problems. And the percentage of times a certain problem was reported by three instructors is presented, too. Each session, three distinct listening and interpretation activities including news, movie clips, monologues, lectures etc. were aurally and orally practiced and instructors were asked to mark on the categorized problems or write whether a certain problem occurred in that session. They were also interviewed at the end of each session and their viewpoints were recorded and later checked against their instantaneous written reports. Dependability of the researchers' interpretation of the learners' problems was verified by both parties' (learners and instructors) subsequent review and evaluation of those themes (Mackey \& Gass, 2005).

\section{Discussion}

The current study focuses on the listening processing problems and oral interpretation difficulties learners experience and on the way instructors see, report or evaluate these experiences. A qualitative study was carried out and learners' verbal reports during and immediately after the completion of every listening task and oral interpretation were sought for. Initial data analysis helped identify some recurrent issues which were later revised and rethought using data collected from next sessions. To analyze and examine the data garnered from the instructors, the same themes explored from the learners' reflections and reports were employed.

Table 2 indicates the themes extracted from the learners' and instructors' data along with the percentage rate of their reports on each theme. The asterisk shows that the data for both instructors and the learners on a certain theme does not exist:

Table 2. The percentage rate of the students

\begin{tabular}{|c|c|c|c|c|}
\hline $\begin{array}{l}\text { Factors } \\
\text { affecting } \\
\text { listening }\end{array}$ & $\begin{array}{l}\text { Theme } \\
\text { number }\end{array}$ & $\begin{array}{c}\text { learners } \\
\%\end{array}$ & $\begin{array}{c}\text { Instructors } \\
\%\end{array}$ & Themes \\
\hline Affective & T1 & 34.6 & 50 & I feel stressed out when I listen in the group. \\
\hline \multirow[t]{2}{*}{ Factors } & $\mathrm{T} 2$ & 53.9 & 20 & When a listening text takes long I get tired. \\
\hline & T3 & 57.7 & 30 & $\begin{array}{l}\text { I lose my concentration when I don't } \\
\text { understand on my first try. }\end{array}$ \\
\hline
\end{tabular}

ISSN | 2355-3669| E-ISSN | 2503-2518| Volume 6 | Number 2|December 2019|

Available online at http://jurnal.radenfatah.ac.id/index.php/edukasi 


\section{Edukasi}

\begin{tabular}{|c|c|c|c|c|}
\hline $\begin{array}{l}\text { Strategic } \\
\text { problems }\end{array}$ & $\mathrm{T} 4$ & 46.2 & 60 & $\begin{array}{l}\text { I am used to the word by word listening } \\
\text { which doesn't help me. }\end{array}$ \\
\hline \multirow{4}{*}{$\begin{array}{l}\text { Parsing } \\
\text { problem }\end{array}$} & T6 & 51.9 & 65 & $\begin{array}{l}\text { I focus my attention on the words and not } \\
\text { on understanding }\end{array}$ \\
\hline & $\mathrm{T} 7$ & 40.40 & * & $\begin{array}{l}\text { I have trouble in separating the stretch of } \\
\text { sounds due to ... }\end{array}$ \\
\hline & $\mathrm{T} 8$ & 57.7 & * & $\begin{array}{l}\text { I don't understand anything on first try and } \\
\text { I only remember }\end{array}$ \\
\hline & T9 & 51.9 & 65 & $\begin{array}{l}\text { I cannot relate the beginning of the } \\
\text { sentence to its end to } . . .\end{array}$ \\
\hline \multirow[t]{2}{*}{$\begin{array}{l}\text { Processing } \\
\text { speed }\end{array}$} & $\mathrm{T} 10$ & 63.5 & 50 & $\begin{array}{l}\text { I can understand when the speed of the play } \\
\text { is low. }\end{array}$ \\
\hline & T11 & 76.9 & 80 & $\begin{array}{l}\text { I comprehend the text when the words are } \\
\text { clearly and fully pronounced. }\end{array}$ \\
\hline $\begin{array}{c}\text { Oral } \\
\text { Interpretati } \\
\text { on } \\
\text { problem }\end{array}$ & $\mathrm{T} 12$ & 63.5 & 100 & $\begin{array}{l}\text { To orally translate the text I should listen } \\
\text { many times. }\end{array}$ \\
\hline \multirow[t]{2}{*}{$\begin{array}{l}\text { Modality } \\
\text { problem }\end{array}$} & T13 & 50 & 30 & $\begin{array}{l}\text { I understand audiovisual texts more easily } \\
\text { than just audio ones. }\end{array}$ \\
\hline & $\mathrm{T} 14$ & 65 & 70 & $\begin{array}{l}\text { I can understand a listening text when I } \\
\text { already see its written texts }\end{array}$ \\
\hline Difficulty & $\mathrm{T} 15$ & 51.9 & 80 & I don't understand when a topic is unfamiliar. \\
\hline $\begin{array}{l}\text { level of the } \\
\text { material }\end{array}$ & T16 & 65.4 & 60 & $\begin{array}{l}\text { Before listening to a text, some difficult words } \\
\text { must be explained. }\end{array}$ \\
\hline $\begin{array}{c}\text { Gender } \\
\text { voice } \\
\text { effect }\end{array}$ & $\mathrm{T} 17$ & & 30 & $\begin{array}{l}\text { I found that female voice is clearer to } \\
\text { them than the male voice. }\end{array}$ \\
\hline $\begin{array}{l}\text { Accent } \\
\text { effect }\end{array}$ & T18 & 53.9 & $57 \%$ & I can't understand some accents. \\
\hline $\begin{array}{l}\text { Poor voice } \\
\text { quality }\end{array}$ & T19 & 30.8 & 10 & $\begin{array}{l}\text { Poor voice quality in the class is the main } \\
\text { reason for my incomprehension. }\end{array}$ \\
\hline
\end{tabular}

Note : Learners' and the instructors' verbal reports on the explored themes of real time listening and interpretation process.

\section{Affective factors}

\section{Learners}

Affective factors such as stress, concentration and sense of fatigue were frequently reported by learners while doing authentic listening activities. More than half the students $(57 \%)$ verbalized that when their initial attempt to understand led to fiasco they lost their concentration. Listening processing in L2 is directly related to affective aspect. When the listener is unable to

ISSN | 2355-3669| E-ISSN | 2503-2518| Volume 6| Number 2|December 2019|

Available online at http://jurnal.radenfatah.ac.id/index.php/edukasi 
grasp the intended message, he will feel frustrated and may lose concentration. A learner recounted:

When I don't understand the first time I abandon the listening, I lose my concentration and have no interest in holding on to the (aural) text. (Translated from Persian)

This finding is consistent with that of Noro (2006) whose Japanese college students reported to have experienced concentration failure as obtained by questionnaire and oral interviews. Fifty four percent $(53.9 \%$ ) of the students reported to have felt exhausted when the listening activity took. long. Less proficient L2 learners, due to the difficulties with attention, and possible limited capacity of their short-term memory feel worn out when listening takes a bit longer.

\section{Instructors}

Instructors reported loss of concentration for the listeners in only one third $(30 \%)$ of the cases which was not higher as compared to learners' own report of concentration failure. Attentiveness within the duration of listening process is mostly an internal phenomenon which instructors may not be aware of although they watch the listeners apparently focusing on the aural/oral task. Only in one fifth of the cases $(20 \%)$ did instructors verbally report learners' experiencing fatigue when they prolonged the time of the listening tasks which is really lower in comparison to verbal report of the $53.9 \%$ by the learners. This indicates that the challenging minutes of listening and interpretation process when extended may quickly exhaust the listeners while the instructors are ignorant of this fact. Instructors in the current study observed students feeling stressed out in 50 percent of the incidents. An instructor noted:

"They looked stressed out when they listened to the audio text played with high speed".

This is high as it is compared to the verbal report of 34.6 percent by the learners. Instructors asking listeners for an interpretation of a piece of a text observed that they were feeling stressed out to answer the instructor and even distorted the whole message. This finding is never at odds with the expectations of the other teachers since the existence of the psychological reality of the construct of listening stress has been verified by some previous studies (Noro, 2006; Elkhafifi, 2005; Gonen, 2009). Gonen attributes this listening anxiety to many factors such as the authenticity of the listening text, incomprehensibility of the listening material and some external environmental factors such as noise and inaudibility.

\section{Strategic problems \\ Learners}

Students' verbal reports display that they mostly employ bottom-up strategies in which they focus on the words and not on the message when listening in L2. Fifty two percent $(51.9 \%)$ of the learners wrote that they were used to this inefficacious strategy of focusing on words and not on understanding the message. The reason may be attributed to their poor language proficiency (Fewel, 2010) which makes them opt for a listening strategy which they wrongly assume to be instrumental (Zhang \& Goh, 2006). Forty six percent (46. $2 \%$ ) of the students said that they were used to the word by word listening. One wrote:

My problem in listening is that I listen word by word and I don't understand the whole meaning.

ISSN | 2355-3669| E-ISSN | 2503-2518| Volume 6| Number 2|December 2019|

Available online at http://jurnal.radenfatah.ac.id/index.php/edukasi 
Although they believed that the way they approached and tackled listening puzzle was not conducive to understanding the message, they tried to apply it in real time processing.

\section{○ Instructors}

Many cases of bottom-up processing were reported by the instructors. They constantly pointed out that many students were attending to the words in order to decipher the meaning. In $65 \%$ of the listening incidents, the instructors reported that the focal attention of the leaners was on the words. This result is in harmony with the verbalized ideas from the learners themselves $(51.9 \%)$. Further, the instructors observed that the learners were following listening word by word (in $60 \%$ of the cases) which is relatively high in comparison to the learners' own report. This result is also in line with Graham's (2006) finding in which subjects pointed out that they focused on individual words and panicked that everything was not understood.

\section{Parsing problem \\ ○ Learners}

Fifty seven percent of the listeners claimed that they did not understand anything on first try and they only remembered a few unrelated words. They were not able to create a mental representation from the words heard. Failure to obtain the intended message on first try may be relevant to the lower linguistic command or lack of experience in the oral interpretation of authentic speech. Some students provided an explanation for their incomprehension by citing:

a. I think I have not learnt to listen well and I want you to belp me.(translated from Persian)

b. I only remember some irrelevant words and this is due to the way the words are pronounced. (translated from Persian)

The second note implies that the learner may not be used to the authentic texts as they are mostly instructed using graded texts. According to Wang (2010), learners may already be acquainted with the words in print but yet be unable to identify them when they encounter them in speech.

Half of the students $(51.9 \%)$ stated that they could not relate the beginning of a sentence to its end to make sense of the sentence. This again indicates that the learner could not make a mental picture of the sentence heard since he/she could not see how the items from the initial and the final parts were connected in any meaningful way. Meanwhile, less than half of the learners $(40.40 \%)$ reported that they have trouble in separating the stretch of sounds due to the different/unclear pronunciation. Verbal reports from some listeners showed they were not able to chunk streams of speech attributing it to their lack of familiarity with authentic pronunciation.

\section{- Instructors}

Out of the three issues which learners had constantly reported only one of them was taken into account by the instructors. They recounted that in $65 \%$ of the listening events the listeners had trouble relating the beginning of the sentence to its end to comprehend a sentence. This finding implies that failure to take the lexical elements of the whole sentence into account in oral interpretation is a common phenomenon as half of the learners reported it $(51.9 \%)$. When they were asked by the instructors to translate the listening pieces just heard they only provided them with some words from the initial and final portions of the text. One instructor recounted: 
As if learners only listened to the beginning and the ending words and didn't try to get the intended message when they listened for the first time.

One part of the above issue can be confirmed to some extent by the results from Goh's (2000) study where her participants explained that they understood most of the words but they couldn't put them together. This indicates that the first listening processing attempts by learners with low proficiency often lead to failure.

\section{Processing speed \\ - Learners}

Different overlapping issues were collapsed into the category of processing speed. More than two -thirds of the learners $(76.9 \%$ ) cited that they could be able to comprehend the text when the words (were) clearly and fully pronounced. This theme was included under the speed of processing category because the learners believed this full and clear pronunciation was possible under low rate of speech delivery in which they could follow the trace of many possible words, thereby contributing to the whole meaning. A student wrote:

I think they are not pronouncing the words fully when they are speaking fast and I can't distinguish the words in such speed. (Translated from Persian)

To put their knowledge of the above-mentioned listening difficulty differently, $63.5 \%$ of the participants reported that they can understand when the speed of the play is low:

I think I will understand if the speed of the listening is low and the instructor has to play it slowly for us to understand.

Such writings from the participants in the current study are reminiscent of Myung- Hee, a student who raised his hand in the classroom and said "Teacher the tape is too fast and I can't catch the words" and the teacher jokingly replied "the tape is not too fast you just need to listen faster" (cited in Renandya, 2012, p.5).

\section{○ Instructors}

In more than two-thirds of the listening tasks $(80 \%)$, instructors observed that learners suffered from speedy delivery and the problem was alleviated to some degree "when the words were clearly and fully pronounced". Instructors reported that they often tried to repeat the sentences for the students and fully pronounce the words they did not perceive on their first or second try. This observation confirms the learners' reports where $76.9 \%$ acknowledged that clear pronunciation can facilitate listening comprehension. Meanwhile, in $50 \%$ of the listening and interpretation episodes the instructors directly reported that the students' listening comprehension improved 'when the speed of the play was low'. This result, similarly, is almost in sync with what learners reported (63.5\%), thus approving the contribution of low delivery speed to the listening comprehension in the interpretation programs.

\section{Interpretation problem \\ ○ Learners}

The program aimed at helping learners develop oral interpretation ability. This ability, however, besides requiring a higher command of listening skill, necessitates an active short-term memory to retain what the listener has heard and a powerful long term memory to put the

ISSN |2355-3669| E-ISSN | 2503-2518| Volume 6 | Number 2|December 2019|

Available online at http://jurnal.radenfatah.ac.id/index.php/edukasi 
information into context (Phelan, 2001). In the present study more than half the learners, (63.5 $\%$, claimed to be requiring many times of listening to the same piece before they are able to orally translate it. Some learners cited:

To orally translate a text I should have the text in front of my eyes or I can't remember them. (translated from Persian)

While listening I think I understand what is what but in translation I see I have nothing to say. (translated from Persian)

Reflections above indicate that oral interpretation both needs a complete understanding of the text and requires a powerful memory or processing capacity to reconstruct the speech (Gile, 1992).

\section{○ Instructors}

Instructors claimed that in all the interpretation activities that learners were engaged they encountered interpretation problems $(100 \%)$. Teachers told that the learners were not able to orally translate as well as expected although they had transcribed and listened many times. Although more than half of the learners, that is $(63.5 \%)$, verbalized having an interpretation problem, this is really low considering teachers' report of the same activity which indicates that in all the listening episodes (100\%), all learners faced interpretation obstacles.

\section{Modality problem \\ ○ Learners}

Sixty five percent of the learners reported that their listening comprehension was facilitated when they already had access to its written mode and $50 \%$ recounted that their comprehension improved when listening was accompanied by the sight using audiovisual means. The bases for such statements were not merely on beliefs but on the experiences they had while working in the classroom.

\section{○ Instructors}

The teachers observed that in $70 \%$ of the cases when the participants had access to a written text of an oral file they were able to both understand and reconstruct the message in oral interpretation phase. This result verifies learners' understanding of their listening process as it is related to the contribution of the written text to its oral mode. However, the instructors reported that only in $30 \%$ of the listening activities visual means could further contribute to the listening comprehension. The effect of multimodality on listening comprehension has been proven by some studies e.g. Kon (2002, quoted in Chapelle, 2003,) investigating the comprehension of a lecture delivered in various modes verified the multimodality principle. Guichon and Mclornan's (2008) study indicated that L2 subtitles are more helpful in teaching listening.

\section{Difficulty level of the material \\ ○ Learners}

This category includes topic familiarity and lexical knowledge as both impinge upon the comprehensibility of a text. Fifty two percent $(51.9 \%)$ of the students claimed that when the topic is not familiar comprehension is hindered. Prior knowledge about a topic helps top-down processing and makes appropriate inferencing possible and rich background knowledge may compensate for the poor linguistic knowledge (Eysenck \& Keane, 1995; Schmidt-Rinehart, 
1994). Sixty five percent $(65.4 \%)$ of the listeners reported that before listening to a text, some difficult words must be explained. Respecting the contribution of the vocabulary knowledge to listening comprehension there have been contradictory evidences. Chang and Read (2006) found that vocabulary instruction was the least useful form of support for listening comprehension while Mecartty (2000) and Field (2008) claimed that vocabulary knowledge played an important role in L2 listening comprehension ability of the students.

\section{○ Instructors}

As claimed by the teachers in $80 \%$ of the listening events, students' listening comprehension was hampered when the topic was unfamiliar. They believed that background knowledge has a significant role in facilitating listening comprehension of interpretation students. They also cited (in $60 \%$ of the listening incidents) that comprehension was enhanced when new lexical items were explained to the listeners. As this study indicates, teachers' observation verifies the learners' reports in terms of both the effect of topic unfamiliarity and lexical knowledge on the listening comprehension. Given the newness of the topic, teachers, dealing directly with the learners in the classroom, reported more cases of incomprehension $(80 \%)$ than those reported by the learners themselves $(51.9 \%)$. Familiarity with a text makes its comprehension easier as it enables the listeners to relate it to their own background knowledge (Gebhard, 2000). Goh (2013), discussing the factors affecting the listening processing both in English for Specific Purposes (ESP) and English as a Second Language (ESL), considers vocabulary as one of the knowledge sources of listening comprehension.

\section{Accent effect \\ - Learners}

Fifty three percent $(53.9 \%)$ of the listeners held the view that their listening comprehension was affected by the accent the speakers had. One cited:

I am not used to the British accent and I get irritated when I don't understand it.

Goh's (1999) study confirms the current finding in terms of accent effect. Speakers' accent was among the five factors mentioned by two-thirds of the participants investigated by Goh.

\section{○ Instructors}

As recounted by the instructors, in $57 \%$ of the listening and interpretation events, the accent of the speaker influenced the listeners' comprehension and interpretation. They reported that most of the learners were not used to the British accent since they were almost always practicing with audiovisual means with American speakers. The degree of congruence was high in accent effect. As the above data show, more than half the learners stated that their comprehension was affected by the accent the speakers spoke; and similarly, the instructors observed that in more than half the listening and interpretation incidents the learners encountered listening comprehension problems engendered by the accent.

To put it into nutshell, results revealed congruencies between teachers and students on many of the categorized problems such as ineffective strategy of focusing on words, speedy delivery, difficulty level of the material, accent effect and parsing problem as verbally reported by listeners and instructors. The study also showed discrepancies on a few issues including modality and affective factors such as stress, sense of fatigue and concentration loss. As it is clear, the gap between the students and

ISSN |2355-3669| E-ISSN | 2503-2518| Volume 6| Number 2 |December 2019|

Available online at http://jurnal.radenfatah.ac.id/index.php/edukasi 
instructors seems to be more in affective aspects than in other areas since they pertain to internal concerns of the learners and are often extraneous to instructors' classroom planning.

\section{Conclusion and the Implications}

Because listening pursues different goals in different contexts (Goh, 2013) and the variables negatively influencing the instantaneous listening processing differ, taking steps to explore such factors in a specific context is of utmost importance for both the instructors and the students. Thus, to achieve this aim, current study attempted firstly to identify the listening processing and interpretation obstacles and secondly to compare learners and instructors in terms of their knowledge and perception of the same problems. The introspection techniques, observation and interviews showcased some issues impacting listening processing. They include affective issues, strategic problems, parsing problems, processing speed, interpretation (oral translation) problems, modality and accent effect. Although the instructors and the learners agreed on most of the issues within some core categories, some areas of incongruence were also discovered.

The instructors, as admitted by the learners themselves, observed that their participants were applying erroneous strategies in their listening and interpretation process. In their attempt to understand the oral text, they were attending to the individual words in order not to miss any message. Meanwhile, both the instructors and learners were unanimous on the theme that the speed of delivery impeded the learners' listening comprehension and interpretation task. The students were unable to process the incoming input since it was immediately superseded by the newly entering data (Goh, 2000) implying that for the learners to process a language in which they are not completely proficient is very demanding. The present study showed that the listeners' problem was even aggravated by their limited short term memory capacity when they were required to orally interpret a sentence. It was also acknowledged by both learners and teachers that topic newness and limited vocabulary knowledge have a negative effect on listening processing and interpretation activity. Teachers observed more incidents of comprehension failure by the listeners due to the topic unfamiliarity suggesting that background knowledge plays an important role in the L2 listening comprehension.

Another factor relating to the listening and interpretation obstacles was parsing problem where learners' experiences and teachers' observation of those experiences overlapped to some extent. The study found that failure to take the whole sentence's lexical elements into account in listening processing and subsequently in oral interpretation is a common phenomenon. Given the modality issue, while verbal reports from both teachers and learners revealed that access to 'written version' of an oral text would ease the listening processing, the observation of the instructors was not in accord with the verbal reports of the learners with regard to the amount of contribution of audiovisual aids such as pictures, gestures, actions, etc. to the listening comprehension. Instructors observed that even when the sound was accompanied by the images and actions they didn't have any particular impact on the comprehensibility of the texts. This discordancy in reports might be due to the fact that instructors' perception of the learners' listening processing usually came from the way learners "acted" in the classroom e.g., by responding to instructors' questions, reproducing the text, or orally translating, all requiring retention of information in the memory and (re )production capacity. However, when learners were asked to verbalize about their ability to process a listening text on line, they considered the comprehension phase which suggests that teachers must differentiate the listening processing

ISSN |2355-3669| E-ISSN | 2503-2518| Volume 6| Number 2 |December 2019|

Available online at http://jurnal.radenfatah.ac.id/index.php/edukasi 
from the production activities and must not compound the listening activities by adding production phase for low proficient students.

Another interesting finding came from the accent effect where the reports from either group indicated the unpropitious effect of an exposure to unfamiliar accent. Both learners and instructors equally articulated that the learners couldn't understand when the text included speakers with British accent. This may suggest that language variety cannot be taken for granted and English language programs must have learners get acquainted with at least such two established English varieties as American and British.

Much incongruence in reports was identified in terms of affective factors such as stress, concentration and sense of fatigue. Unlike the observation of the instructors, more than half the students experienced higher fatigue and concentration loss implying that the challenging listening and interpretation processes may exhaust the listeners while the instructors are ignorant of this fact. Furthermore, listening in a L2 requires much concentration which can tire out the learners if it takes too long.

The present study suggests that instructors and learners may see the L2 classroom activities differently but a collective and complementary knowledge garnered from both sides can lead to a learning environment which facilitates and improves L2 acquisition. Knowledge of learners' affective needs particularly in challenging activities such as listening and oral translation can result in better classroom planning and, in turn, better concomitant learners' achievements.

Degree of congruence and/or incongruence between student interpreters and instructors in terms of the beliefs and knowledge of the same listening and interpretation experiences afford some practical implications for interpretation and translation practitioners. Interpreter trainers, for example, need to allow low proficient trainees sufficient background knowledge, provide them with opportunities to develop lexical ability, observe appropriate speed of delivery, and facilitate anxiety. Trainers are also encouraged to offer trainees propitious opportunities for practicing and tackling oral interpretation tasks, particularly in the case of the simultaneous mode which requires higher competency and attention to perform the interpretation task while the listening is still in progress.

But, in closing, some words worthy of note are that this study was basically qualitative and exploratory and no generalization can be claimed based on our findings as only descriptive statistics were used in analyzing and reporting the results. Furthermore, subjects attending our study were intact groups who were not randomly selected.

\section{References}

Anderson, J. R. (2009). Cognitive psychology and its implications (seventh edition). New York, NY: Worth Publishers.

Anderson, J. R. (1985). Cognitive psychology and its implications. New York, NY: Freeman.

Brown, G. (1995). Dimensions of difficulty in listening comprehension. In D. Mendelsohn \& J, Rubin (Ed.), A Guide for the Teaching of Second Language Listening (pp. 59-73). San Diego, CA: Dominie Press.

Buck, G. (2001). Assessing listening. Cambridge, UK: Cambridge University Press.

Chang, A. C. S. (2008). Listening strategies of L2 learners with varied test tasks. TESL Canada Journal, 25(2), 1-26.

Chang, A. C. S. \& Read, J. (2006). The effects of listening support on the listening performance of EFL learners. TESOL Quarterly, 40, 375-397.

ISSN |2355-3669| E-ISSN | 2503-2518| Volume 6| Number 2 |December 2019|

Available online at http://jurnal.radenfatah.ac.id/index.php/edukasi 
Chapelle, C. A. (2003). English language learning and technology: Lectures on applied linguistics in the age of information and communication technology. Amsterdam: John Benjamins.

Cross, J. (2009). Effects of listening strategy instruction on news videotext comprehension. Language Teaching Research, 13, 151-176.

Eastman, J. K. (1993). C-words and F-words: The importance of distinguishing content and function in teaching second language LC. System, 21, 495-502.

Elkhafaifi, H. (2005). Listening comprehension and anxiety in the Arabic language classroom. The Modern Language Journal, 89, 206-220.

Eysenck, M. W., \& Keane, M. T. (1995). Cognitive psychology (3rd ed.). Sussex : Psychology Press.

Fewell, N. (2010). Language learning strategies and English language proficiency: An investigation of Japanese EFL university students. TESOL Journal, 2, 159-174.

Field, J. (2009). More listening or better listeners?. English Teaching Professionals, 61, 12-14

Field, J. (2008). Listening in language classroom. Cambridge, UK: Cambridge University Press.

Field, J. (2004). An insight into listeners' problems: Too much bottom-up or too much topdown? System, 32(3), 363-377.

Friedman, D. (2012). How to collect and analyze qualitative data. In A. Mackey \& S. Gass (Ed.). Research Methodologies in Second Language Acquisition (pp. 180-200). Malden, MA: WileyBlackwell.

Gebhard, J. (2000). Teaching English as a foreign or second language: A teacher self- development and methodology guide. United States, US: The University of Michigan Press.

Gile, D, (1995). Basic concepts and models for interpreter and translator training. Amsterdam \& Philadelphia: John Benjamins.

Gile, D, (1992). Les fautes de traduction: une analyse pédagogique, Meta, 37(2), 251-262.

Goh, C. (2013) ESP and listening: In B. Paltridge \& S. Starfield (Ed.). The Handbook of English for Specific Purposes (pp.54-76). Malden, MA: Wiley-Blackwell

Goh, C. (2008). Metacognitive instruction for second language listening development: Theory, practice and research implications. RELC Journal, 39(2), 188-213.

Goh, C. (2000). A cognitive perspective on language learners' listening comprehension problems. System, 28(1), 55-75.

Goh, C. (1999). How much do learners know about the factors that influence their listening comprehension?. Hong Kong Journal of Applied Linguistics, 4(1), 17-42.

Gonen, M. (2009). Proceedings of the 5th WSEAS/LASME from EDUTE' 09: International Conference on Educational Technologies. Spain: University of La Laguna.

Guichon, N., \& McLornan, S. (2008). The effects of multimodality on L2 learners: Implications for CALL resource design. System, 36, 85-93.

Graham, S. (2006). Listening comprehension: The learners' perspective. System, 34(2), 165-182.

Hasan, A. (2000). Learners' perceptions of listening comprehension problems. Language, Culture and Curriculum, 13(2), 137-153.

Jinhong, B. (2011). Exploring students' use of metacognitive strategies in listening comprehension of the TEM4. (Bachelor Thesis). Kristianstad University, Swedia.

Johnson, K. (2008). An introduction to foreign language learning and teaching (2nd ed.). Harlow, England: Pearson.

Kemp, J. (2010). The listening log: Motivating autonomous learning. ELT Journal, 64, 385-395. doi: $0.1093 /$ elt/ccp099

ISSN | 2355-3669| E-ISSN | 2503-2518| Volume 6 | Number 2|December 2019|

Available online at http://jurnal.radenfatah.ac.id/index.php/edukasi 
Kon, C.K. (2002). The influence on outcomes of ESL students' performance strategies on a CALL listening comprehension activity. (Unpublished MA thesis), Department of English, Iowa State University, USA.

Leeser, M. J. (2007). Learner-based factors in L2 reading comprehension and processing grammatical form: Topic familiarity and working memory. Language Learning, 57(2), 229_ 270.

Lynch, T. (2009). Teaching second language listening. Oxford, UK: Oxford Press.

Lynch, T., \& Mendelsohn, D. (2009). Listening. In N. Schmitt (Ed.) Introduction to Applied Linguistics, (p. 181-196). London: Arnold.

Mackey, A., \& Gass, S. (2016). Second language research: Methodology and design (2 ${ }^{\text {nd }}$ ed.). New Jersey, NJ: Lawrence Erlbaum Associates.

Mackey, A., \& Gass, S. M. (2005). Second language research: Methodology and design. Mahwah, NJ: Lawrence Erlbaum.

Mahmoodzadeh, K. (1992). Consecutive Interpreting: Its principles and techniques. In C. Dollerup \& A. Lindegaard (ed.). Teaching Translation and Interpreting (pp. 231-236). Amsterdam: Benjamins.

Mecartty, F. H. (2000). Lexical and grammatical knowledge in reading and listening comprehension by foreign language learners of Spanish. Applied Language Learning, 11, 323348.

Noro, T. (2006). Developing a construct model of "listening stress": A qualitative study of the affective domain of the listening process. Annual Review of English Language Education in Japan, 17, 61-70.

O'Malley, J. M., Chamot, A.U., \& KuÈpper, L., 1989. Listening comprehension strategies in second language acquisition. Applied Linguistics 10, 418-437.

Phelan, M. (2001). The interpreter's resource. Clevedon: Multilingual Matters.

Renandya, W. A. (2012). Five reasons why listening strategies might not work with lower proficiency learners. English Language teaching World Online; Voices from the classroom (ELTWO), Vol.3. http://blog.nus.edu.sg/elttwo/2012/02/22/ five-reasons -whylistening- strategy-instruction-might-not-work-with-lower-proficiency-learners /

Rost, M. (2001). Teaching and researching listening. London: Longman.

Schmidt-Rinehart, B. (1994). The effects of topic familiarity on second language listening comprehension. Modern Language Journal, 18, 179-89

Stahr, L. S. (2009). Vocabulary knowledge and advanced listening comprehension in English as a foreign language. Studies in Second Language Acquisition, 31, 577-607.

Vandergrift, L. (2011). Teaching interactive listening. In H. P. Widodo \& A. Cirocki (Eds.), Innovation and creativity in ELT methodology (pp. 1-14). New York: Nova Science Publishers.

Vandergrift, L. \& Tafaghodtari, M. (2010). Teaching L2 learners how to listen does make a difference: An empirical study. Language Learning, 60(2), 470-97.

Vandergrift, L. (2007). Recent developments in second and foreign language listening comprehension research. Language Teaching, 40(3), 191-210.

Vandergrift, L. (2006). Second language listening: Listening ability or language proficiency?. The Modern Language Journal, 90, 6-18.

Vandergrift, L. (2005). Relationships among motivation orientations, metacognitive awareness and proficiency in L2 listening. Applied Linguistics, 26(1), 70-89.

ISSN | 2355-3669| E-ISSN | 2503-2518| Volume 6 | Number 2|December 2019|

Available online at http://jurnal.radenfatah.ac.id/index.php/edukasi 
Vandergrift, L. (2004). Listening to learn or learning to listen? Annual Review of Applied linguistics, 24, 3-25.

Vogely, A. J. (1995). Perceived strategy use during performance on three authentic listening comprehension tasks. The Modern Language Journal, 79(1), 41-56.

Wang, L. (2010). Chinese EFL learners' listening comprehension difficulties- A comparison between teacher and student perspectives. (Unpublished MA thesis), National Institute of Education, Nan yang Technological University, Singapore.

Wenden, A. (1999). An introduction to metacognitive knowledge and beliefs in language learning: Beyond the basics [Special Issue]. System, 27, 435-441.

Zhang, D., \& Goh, C. (2006). Strategy knowledge and perceived strategy use: Singaporean students' awareness of listening and speaking strategies. Language Awareness, 15(3), 199-219.

ISSN | 2355-3669| E-ISSN | 2503-2518| Volume 6| Number 2|December 2019|

Available online at http://jurnal.radenfatah.ac.id/index.php/edukasi 